\title{
Activity Guided Isolation and Characterization of Antiplasmodial Agents of some Local medicinal Plants
}

\author{
${ }^{*}$ S.W. Hassan, 2 S. Verma, ${ }^{2}$ S.K.Srivastava, and ${ }^{3 S}$. Dwarn \\ 1Department of Biochemistry, Usmanu Danfodiyo University, P.M.B. 2346, Sokoto, Nigeria, \\ 2 Medicinal Chemistry Departments, Central Institute of Medicinal and Aromatic plants, Lucknow, India \\ IIn vivo animal Testing Unit, Central Institute of Medicinal and Aromatic plants, Lucknow, India \\ [Corresponding Author, Email: hassanwara@gmail.com; 留: +2348036355866]
}

\begin{abstract}
Combined Plant Mixture (CPM) in ratio of 1:1 (Vitex doniana, Diospyros mesipiliformis, Acacia polyacantha, Parinari macrophylla, Ficus sycomorus and Parkia biglobosa) was extracted with methanol and screened for antimalarial activity. The CPM Methanol extract residue was suspended in water and fractionated with Hexane (HX), Ethylacetate (EA) and n-Butanol (BUT). The Methanolic CPM extract has shows some antimalarial activity with Mean Survival Times (MST) of 10.16 to 12.16 days. All the mice in control group were found dead on $14^{\text {th }}$ day of study and one mice was still alive on $14^{\text {th }}$ day in both the groups with $15 \%$ and $30 \%$ parasitaemia against Plasmodium yoelli nigeriensis $\mathrm{N}_{67}$ and Plasmodium berghei $\mathrm{K}_{173}$ respectively. The EA fraction was the most active against $P$. yoelli nigeriensis $N_{67}$ having 2 mice surviving up to $14^{\text {th }}$ day with $5.5 \%$ parasitaemia and MST of 13.4 days. Fractions of water (WT), HX and BUT have 12.5, 25, and 100\% (dead) parasitaemia with mean survival times of 12.6, 9.33 and 8.5 days against $100 \%$ (dead) parasitaemia and 8.20 days of MST when compared with control. $\mathrm{HX}$ fraction was the most active against $P$. berghei $\mathrm{K}_{173}$ followed by BUT fraction with one mice surviving up to $14^{\text {th }}$ day without parasitaemia but with MST of 15.0 and 13.5 days respectively. EA and WT fractions have 22.66 and $100 \%$ (dead) parasitaemia with mean survival times of 11.80 and 10.80 days respectively. Chromatographic separation of EA fraction of the CPM extract resulted in the isolation of Gallic acid(Figure 2, Fractions 79-83), 3ß-OH-a-amyrin(Figure 3, Fractions 45-46), 5,7,3',4',5'pentahydroxy-3-0-glucophyranoside flavones(Figure 4, Fractions 128-157)-[myricetin 3-0- $\beta$-rhamnopyranoside], $5,7,3^{\prime}, 4^{\prime}$ tetrahydroxy-3-0-glucopyranoside flavones(Figure 5 , Fractions 126-141)-[quercetin 3-0- $\beta$ rhamnopyranoside], and 3,5,7,3',4'-Pentahydroxy flavones (Figure 6, Fractions 87-112)-[quercetine]. The compounds were characterized using ESI-MS, IR, ${ }^{1} \mathrm{H} \mathrm{C}{ }^{13}, \mathrm{HMBC} / \mathrm{HSQC}$ and COSY-NMR data. These findings suggest that the combined extracts possess antiplasmodial properties.

Keywords: Antimalarial, combined plant mixture, ${ }^{1} \mathrm{H}^{13} \mathrm{C}$ NMR, activity guided fractionation
\end{abstract}

\section{INTRODUCTION}

According to the WHO estimates, there were about 219 million cases of malaria in 2010 and an estimated 660,000 deaths. Africa is the most affected continent having $90 \%$ of malaria deaths (WHO 2012). In Nigeria, between 2000 and 2010 , around $50 \%$ of the population had one episode of malaria per year and children below 5 years had two or four attacks (National Guidelines for Diagnosis and Treatment of Malaria, 2011). The malaria problem has been exacerbated by chloroquine resistant parasite strains which have been reported from all parts of Nigeria (Olanrewaju and Johnson, 2001). Spread of multidrug-resistant Plasmodium falciparum has highlighted the need to develop new antimalarial drugs that are affordable for developing countries where malaria is prevalent (Vial 1996; Wernsdorfer and Trigg 1988). A cornerstone of policies to reduce malaria is early diagnosis and prompt effective therapy. Recently, combination of plants as therapies in Nigeria has emerged as an effective alternative to current drugs used in combating malaria due to emerging parasite resistance to these agents.

Herbal drugs may provide an option for treatment of malaria and may provide alternative to the expensive antimalarial drugs. Phytocompounds have been earlier used for antiplasmodial activity (Samy et al., 2011). Some of the plants used in this study have been reported to have pharmacological properties (Atawodi 2005; Ladeji et al., 2005; Hassan et al., 2007; Okpanach, 2010).

Vitex doniana is called Black plum and belongs to the family Verbenaceae. It is used locally for the treatment of leprosy, genital stimulants and as sedatives. Diospyros mesipiliformis, member Ebenaceae, is 
Jackal berry tree and is traditionally used to stop purging, for antimalarial activity and to enhance fertility. Acacia polyacantha belongs to the family Fabaceae. It is commonly called White-stem thorn and is used traditionally to treat snake bites. Parinari macrophylla, (Ginger bread plum) belongs to Chrysobalanaceae family and is used locally for the treatment of skin diseases and malaria. Ficus sycomorus (Bush fig) belongs to the family Moraceae and is used for the treatment of coughs, dysentery, ringworm and jaundice. Parkia biglobosa (African locust bean) belongs to the family Fabaceae and is tradomedically used as food and medicine (Arnold and Gulumian, 1984, Burkill, 2000, Mandu and Tengnas, 2005),

The six plants used in the present study are recently used in combination for the treatment of malaria in Northern Nigeria but their claimed antimalarial properties are investigated to obtain potential sources of antimalarial agents. To the best of our knowledge isolation and characterization of the bioactive principles from this combined plant mixture have not been reported so far. Therefore, it is worthwhile to present report on the activity guided fractionation, isolation and characterization of antimalarial agents from these plants.

\section{MATERIALS AND METHODS Plant Material}

The leaves, roots and stems of the selected plants were collected from the adjoining area of Usmanu Danfodiyo University (U.D.U.), Sokoto, Nigeria. After taxonomic identification at Botany Unit (U.D.U.), the plant parts were open air-dried under the shade and pulverized into a moderately coarse powder.

\section{Extraction Procedure}

The combined plants parts (leaf, stem bark and root) in ratio of 1:1 (Vitex doniana, Diospyros mesipiliformis, Acacia polyacantha, Parinari macrophylla, Ficus sycomorus and Parkia biglobosa) were extracted with methanol three times, concentrated and screened for antimicrobial activity. The methanolic residue was further suspended in water and extracted with HX, EA and BUT as in Figure 1. The procedure was repeated to obtain more residues.

\section{Chemicals}

Vanillin from BDH, All other chemicals and solvent used were of analytical grade.

\section{Animals}

Random breed Swiss mice ( $20 \pm 2 \mathrm{~g})$ of either sex were procured from the animal facilities of Central Institute of Medicinal and Aromatic Plants (CIMAP), Lucknow, India. They were maintained on commercial pellet diet and water ad libitum under standard housing conditions. Ethical guidelines on handling and use of experimental animals in accordance with US guidelines as contained in National Institute of Health guide for the care of laboratory animals (NIH publication no. 18-23) and as reported by Zimmerman (1983) were followed.

\section{Malarial parasites}

Rodent malaria parasite Plasmodium yoelii $\mathrm{N}_{67}$ and Plasmodium berghei $\mathrm{K}_{173}$ which are chloroquine resistant and sensitive respectively were used in this study. The parasites were obtained from Central Drug Research Institute (CDRI), Lucknow, India. They were maintained in normal Swiss mice through sequential passages.

\section{Isolation of bioactive compounds from the ethyl acetate fraction (EF) of Combined Plant Mixture (CPM)}

The ethyl acetate fraction (EF) of Combined Plant Mixture (CPM) showed remarkable antimalarial activities, hence eight grams $(8 \mathrm{~g})$ of this fraction were subjected to Vacuum Liquid Chromatographic (VLC) separation over Silica gel $\mathrm{H}$ (average particle size approx. $10 \mu \mathrm{m})$. Stepwise gradient elution of VLC column was carried out with hexane, hexanechloroform, chloroform, chloroform-methanol and methanol. A total of 249 fractions were collected. The fractions were pooled on the basis of their TLC profile as follows:

$\begin{array}{ll}\text { Fractions } & 14-62(270 \mathrm{mg}) \\ \text { Fractions } & 63-73(308 \mathrm{mg}) \\ \text { Fractions } & 152-184(325 \mathrm{mg}) \\ \text { Fractions } & 201-214(524 \mathrm{mg}) \\ \text { Fractions } & 215-230(495 \mathrm{mg}) \\ \text { Fractions } & 231-246(1000 \mathrm{mg})\end{array}$




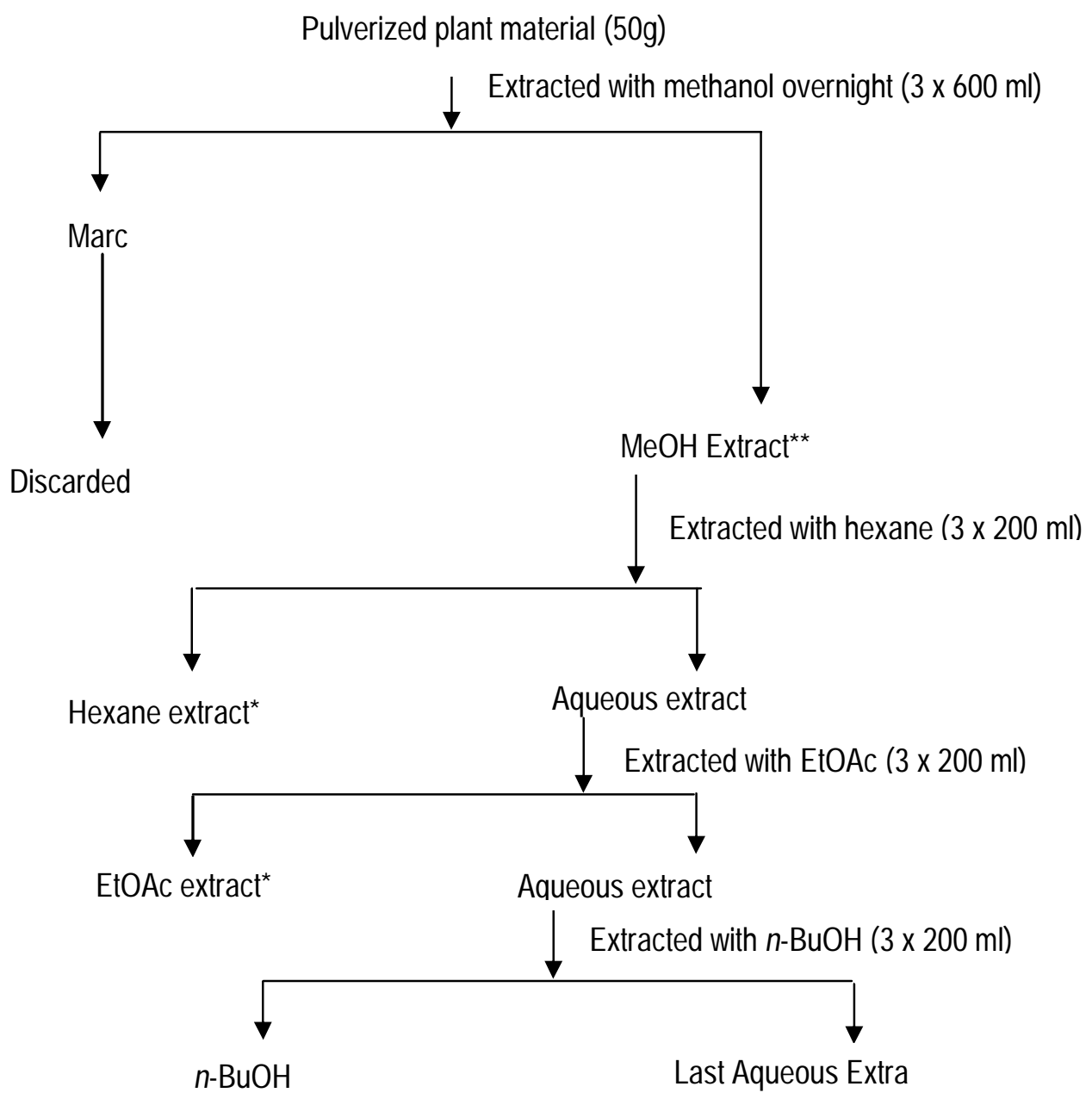

Figure 1: General extraction and fractionation procedure.

\section{General experimental procedures}

The ${ }^{1} \mathrm{H}$ and ${ }^{13} \mathrm{C}$ NMR spectra were recorded on a Bruker Avance $300(300 \mathrm{MHz})$. Column chromatography was performed with silica gel (60-120 mesh). TLCs were run on readymade (Silica gel $60 \mathrm{~F}_{254}, 0.25 \mathrm{~mm}$, $20 \times 20 \mathrm{~cm}$, Merck, Germany) aluminum sheets while preparative TLCs were run on (Silica gel $60 \mathrm{~F}_{254}$, $0.5 \mathrm{~mm}$, glass plates $20 \times 20 \mathrm{~cm}$ ) glass plates from Merck, Germany. Spots on the TLC plates were visualized by spraying with vanillin sulfuric acid and heating the plate in oven for 5 minutes at $100^{\circ} \mathrm{C}$.

\section{Antimalarial activity}

Antimalarial potential (blood schizontocidal action) of the Combined Plant Mixture (CPM) and its fractions (Hexane, Ethylacetate, Butanol, and water) were evaluated according to the standard protocol (Peters, 1975). Extracts were tested against Plasmodium yoelii nigeriensis N67 in Swiss mice at a dose of $1000 \mathrm{mg} / \mathrm{kg}$ body weight with six (6) mice in each group. Six (6) doses of extract from day 0 to day 5 were administered to each group of mice orally. Artesunate at a dose of $100 \mathrm{mg} / \mathrm{kg}$ was given to one group of mice once a day from day 0 to day 4 ( 5 doses). Mice were infected with $1 \times 10^{6}$ parasitized erythrocytes intraperitoneally on day 0 and the treatment was done after 1 hour. All the five extracts were administered once daily by oral route starting from the day of infection (day 0) up to 6 days. Thin blood smears of individual animals of each group of mice were prepared from day 4 and onwards. Smears were fixed with methanol and stained with Giemsa. These smears were examined for percent parasitaemia and their standard derivations were calculated. Extracts were also tested against $P$. berghei infected mice at a dose of $1000 \mathrm{mg} / \mathrm{kg}$ body weight. Six (6) mice were used in each group. Extracts were given from day 0 to day 5 ( 6 doses) to each group of mice orally. Chloroquine at the dose of $10 \mathrm{mg} / \mathrm{kg}$ was given 
to one group of mice from day 0 day 3 orally. Another group of control mice (only infection) received only water and food ad libitum. Mice were infected with $1 \times$ $10^{6}$ parasitized erythrocytes intraperitoneally on day 0 . From day 4 and onwards, blood smears were prepared from tail vein of the mice and stained with Giemsa stain and percentage parasitaemia was recorded by counting parasitized erythrocytes. Mortality of the mice was recorded daily to obtain the Mean Survival Time (MST).

Mean Survival Time (MST) of infected and extract/drug treated batch was obtained by recording the number of mice found dead on different days. This number was multiplied by the corresponding day when they were found dead. The number of mice surviving till the end of the experiment (i.e. days 28) was multiplied by 28 . These days were added and divided by the total number of mice.

\section{Statistical Analysis}

Data were subjected to Analysis of Variance (Instat software) and a $p<0.05$ was considered statistically significant.

\section{RESULTS AND DISCUSSION}

The methanolic extract showed significant $(p<0.05)$ antimalarial activity at 7,10 and 14 days. The Mean Survival Times (MST) of the mice increased by days, which were from $8.16 \pm 2.40$ to $12.16 \pm 1.32$ as compared with control. All the control mice were found dead on $14^{\text {th }}$ day, while one mice was still alive on $14^{\text {th }}$ day in both groups with 15\% and 30\% parasitaemia (Plasmodium yoelli nigeriensis N67 and Plasmodium berghei K173 respectively) (Tables 1 and 2). This prompted us to carry out further fractionation of the CPM methanolic extract. Hence, the left over methanolic extract $(40 \mathrm{~g})$ was further suspended in water and successively fractionated with hexane, ethylacetate and $\mathrm{n}-\mathrm{BuOH}$ (saturated with water).

All the fractions were further screened against $P$. yoelli nigeriensis $\mathrm{N} 67$ and $P$. berghei $\mathrm{K} 173$ (Tables 1 and 2). From Table 1 it is evident that ethylacetate fraction was most active $(p<0.05)$ against $P$. yoelli nigeriensis N67 with 2 mice surviving until $14^{\text {th }}$ day having $5.5 \%$ parasitaemia and MST of 13.4 days when compared with control.. The other significantly $(p<0.05)$ active fractions were water, hexane and butanol respectively with $12.5,25$, and $100 \%$ (dead) parasitaemia and mean survival times of $12.6,9.33$ and 8.5 days against $100 \%$ (dead) parasitaemia and 8.20 days MST when compared with control. Hence the antimalarial activity of the fractions may be represented as: Ethyl acetate fraction $>$ hexane fraction $>$ water fraction $>\mathrm{BuOH}$ fraction

From Table 2, hexane fraction was the most active $(p<0.05)$ against $P$. berghei K173 followed by butanol extract with one mice surviving until $14^{\text {th }}$ day having no parasitaemia with MST of 15.0 and 13.5 days respectively. Other significantly $(p<0.05)$ active fractions were ethylacetate and water with 22.66 and $100 \%$ (dead) parasitaemia and mean survival times of 11.80 and 10.80 respectively when compared with control. Thus, antimalarial activity in the fractions may be represented as: Hexane fraction > BuOH fraction > ethyl acetate fraction $>$ water fraction

Resistance of Plasmodium falciparum to chemical treatment is still important and products isolated from medicinal plants that have potent antiplasmodial action may represent potential sources of new antimalarial drugs (Gasquet et al., 1993).

Results of the antimalarial studies motivated us to carry out activity guided separation of ethylacetate fraction of the CPM. After a series of chromatographic separation as discussed in the experimental section, ethylacetate fraction resulted in the isolation and characterization of bioactive constituents, Gallic acid (Figure 2,), 3ß-OH- $\alpha-$ amyrin(Figure 3,), 5,7,3',4',5'-pentahydroxy-3-0glucophyranoside flavones(Figure 4,)-[myricetin 3-O- $\beta$ rhamnopyranoside], $\quad 5,7,3^{\prime}, 4^{\prime} \quad$ tetrahydroxy-3-0glucopyranoside flavones(Figure 5 ,)-[quercetin 3-O- $\beta$ rhamnopyranoside] and 3,5,7,3',4'-Pentahydroxy flavones (Figure 6,)-[quercetine]. The compounds were characterized using ESI-MS, IR, ${ }^{1} \mathrm{H} \mathrm{C}{ }^{13}$, $\mathrm{HMBC} / \mathrm{HSQC}$ and COSY-NMR data. Phytocompounds are known to destroy DNA and inhibit topoisomerase II and are involved in elevation of red blood cells oxidation (Etkin, 1997, Bonjean, 1988). Flavonoids were reported to have antiparasitic activities against different strains of malaria (Kim et al., 2004, Oliveira et al. 2004, Monbrisome et al., 2006). The Flavonoids (Figures 2 to 6 ) isolated from the ethyl acetate fraction of CPM may be acting in synergy to exert the antimalarial activity observed. These compounds were also reported to have antioxidant and antibacterial properties (Hassan et al., 2013). The results suggest that the combined extracts possess antiplasmodial properties. 
Nigerian Journal of Basic and Applied Science (September, 2013), 21(3): 177-185

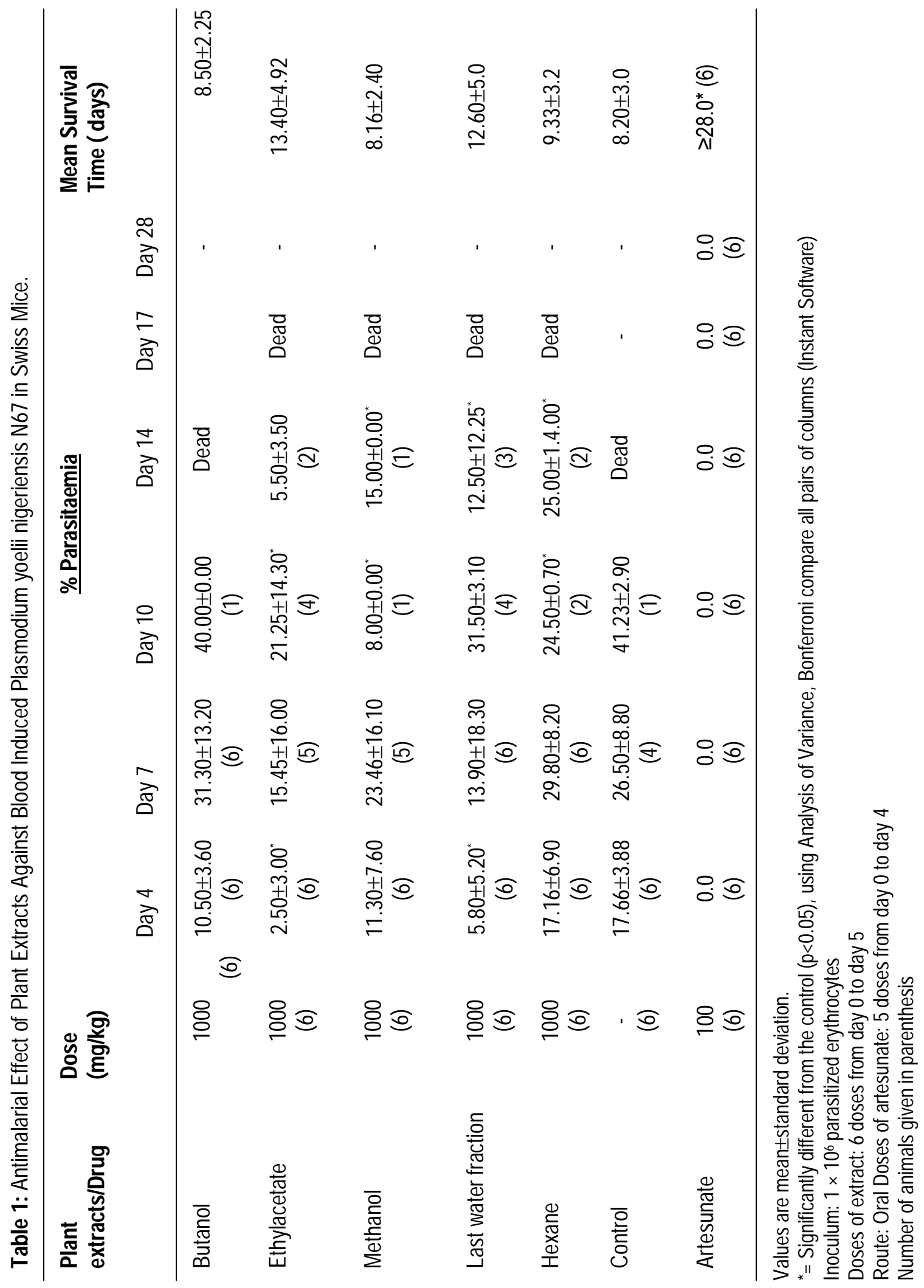




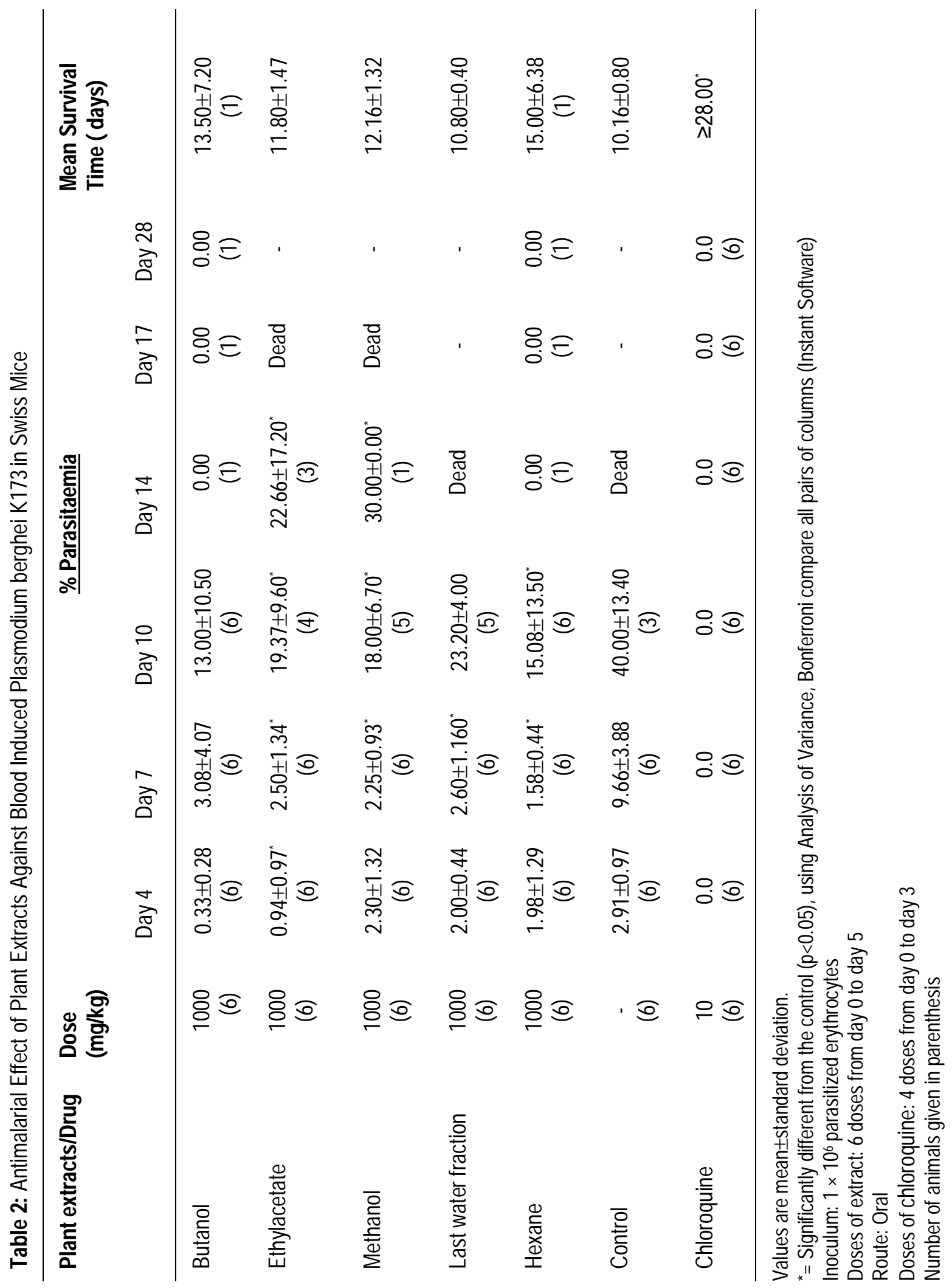




\section{Isolated compounds}<smiles>O=C(O)c1cc(O)c(O)c(O)c1</smiles>

Figure 2: Gallic acid (Fraction 79-83)

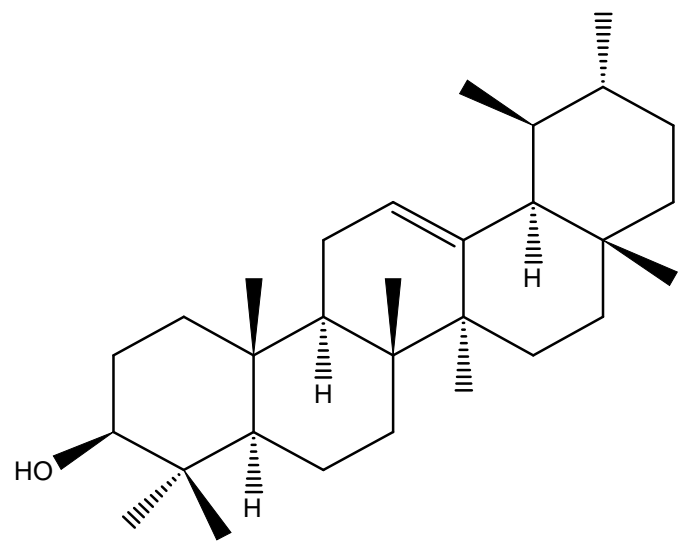

Figure 3: 3ß-Hydroxy-a-amyrin

(Fractions 45-46)

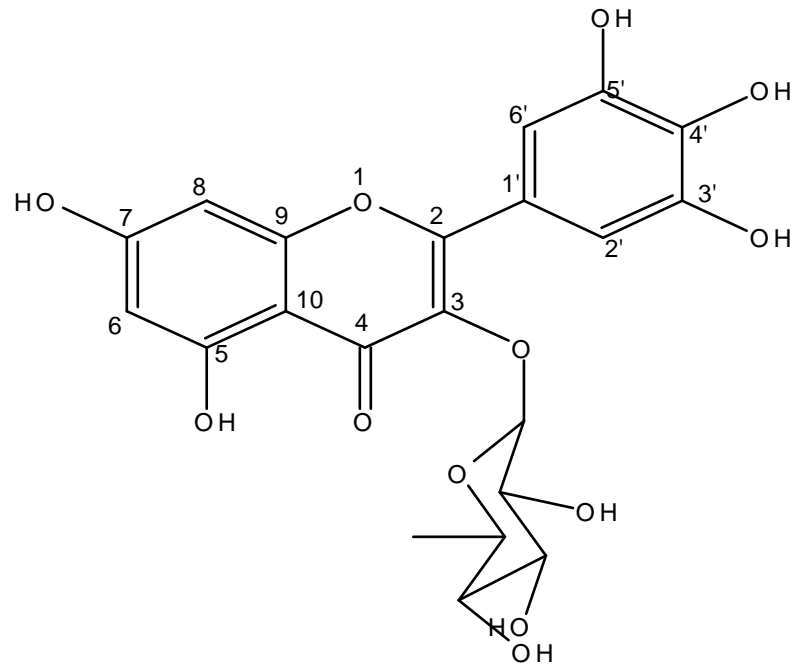

\section{NMR PROPERTIES}

${ }^{1} \mathrm{H} \mathrm{NMR}\left(\mathrm{CDCl}_{3}, 300 \mathrm{MHz}\right): \delta 7.05$ (2H, s, H-3 \& H-7),

${ }^{13} \mathrm{C}$ NMR (CD $\left.30 \mathrm{OD}, 300 \mathrm{MHz}\right): 170.42$ (C-1'), 121.93 (C-1), 110.30 (CH, C-2), 146.35 (C-3), 139.57 (C-4), 146.35 (C5), $110.30(\mathrm{CH}, \mathrm{C}-6)$

\section{${ }^{1} \mathrm{H}$ NMR (MeOD, $300 \mathrm{MHz}$ ):}

$\delta 0.77$ to $1.14(24 \mathrm{H}, 6 x$ ter-Me \& $2 x$ sec-Me $) 1.3(1 \mathrm{H}$, $\mathrm{d}, \mathrm{J}=6.3 \mathrm{~Hz}, 18 \mathrm{a}-\mathrm{H}), 3.20(1 \mathrm{H}, \mathrm{dd}, \mathrm{J}=5.1,1.023 \mathrm{a}-\mathrm{H})$ $5.20(1 \mathrm{H}, \mathrm{t}, \mathrm{J}=3.0,12-\mathrm{H})$

${ }^{13} \mathrm{C}$ NMR $\left(\mathrm{CDCl}_{3}, 300 \mathrm{MHz}\right): 38.76(\mathrm{CH} 2, \mathrm{C}-1), 27.25$ (CH2, C-2), $78.98(\mathrm{CH}, \mathrm{C}-3), 38.76(\mathrm{C}-4), 55.16(\mathrm{CH}$, $\mathrm{C}-5), 18.34\left(\mathrm{CH}_{2}, \mathrm{C}-6\right), 32.91\left(\mathrm{CH}_{2}, \mathrm{C}-7\right), 39.99(\mathrm{CH}$, $\mathrm{C}-8), 47.69(\mathrm{CH}, \mathrm{C}-9), 36.88(\mathrm{C}-10), 23.25\left(\mathrm{CH}_{2}, \mathrm{C}-\right.$ 11), 124.39 ( $\mathrm{CH}, \mathrm{C}-12), 139.30$ (C-13), 42.03 (C-14), $28.08\left(\mathrm{CH}_{2}, \mathrm{C}-15\right), 26.60\left(\mathrm{CH}_{2}, \mathrm{C}-16\right), 33.73(\mathrm{C}-17)$, $59.04(\mathrm{CH}, \mathrm{C}-18), 39.59$ ( $\mathrm{CH}, \mathrm{C}-19), 39.59(\mathrm{CH}, \mathrm{C}-$ 20), $31.23\left(\mathrm{CH}_{2}, \mathrm{C}-21\right), 41.51\left(\mathrm{CH}_{2}, \mathrm{C}-22\right), 28.08$ $\left(\mathrm{CH}_{3}, \mathrm{C}-23\right), 15.62\left(\mathrm{CH}_{3}, \mathrm{C}-24\right), 15.62\left(\mathrm{CH}_{3}, \mathrm{C}-25\right)$, $16.84\left(\mathrm{CH}_{3}, \mathrm{C}-26\right), 23.25\left(\mathrm{CH}_{3}, \mathrm{C}-27\right), 28.08\left(\mathrm{CH}_{3}, \mathrm{C}-\right.$ 28)17.46 $\left(\mathrm{CH}_{3}, \mathrm{C}-29\right), 21.39\left(\mathrm{CH}_{3}, \mathrm{C}-30\right)$.

${ }^{1} \mathrm{H}$ NMR (MeOD, $\left.300 \mathrm{MHz}\right): \delta 6.13(1 \mathrm{H}, \mathrm{d}, \mathrm{J}=2.0 \mathrm{~Hz}$, H-6), $6.29\left(1 \mathrm{H}, \mathrm{d}, \mathrm{J}=2.0 \mathrm{~Hz}, \mathrm{H}-8^{\prime}\right), 6.89\left(2 \mathrm{H}, \mathrm{s}, \mathrm{H}-2^{\prime}\right.$ \& H-6'), $5.25\left(1 \mathrm{H}, \mathrm{d}, \mathrm{J}=1.5 \mathrm{~Hz}, \mathrm{H}-\mathrm{1}^{\prime \prime}\right), 3.43(1 \mathrm{H}, \mathrm{dd}, \mathrm{J}$ $\left.=5.7,9.0 \mathrm{~Hz}, \mathrm{H}-4^{\prime \prime}\right), 3.73\left(2 \mathrm{H}, \mathrm{m}, \mathrm{H}-2^{\prime \prime} \& \mathrm{H}-3^{\prime \prime}\right), 4.17$ (1H, m, H-5"), 0.89 (3H, d, J = 6.0 Hz, H-6"),

${ }^{13} \mathrm{C}$ NMR (MeOD, $\left.300 \mathrm{MHz}\right): \delta 158.41$ (C-2), 136.24 (C-3), 179.57 (C-4), 163.05 (C-5), 99.81 (C-6), 165.83 (C-7), 94.72 (C-8), 159.37 (C-9), 105.79 (C-10), 121.85 (C-1'), 109.59 (C-2'), 146.43 (C-3'), 137.83 (C4'), 146.75 (C-5'), 109.59 (C-6'), 103.56(C-2"), 71.80 (C-3") 73.27 (C-4") 79.45 (C-5") 72.00 (C-6"), 17.62 (C-7")

Figure 4: (Fraction 128-157) = 5, 7, 3', 4', 5' pentahydroxy3-O-glucopyranoside flavones (Myricete 3-O- $\beta$ rhamnopyranoside) 


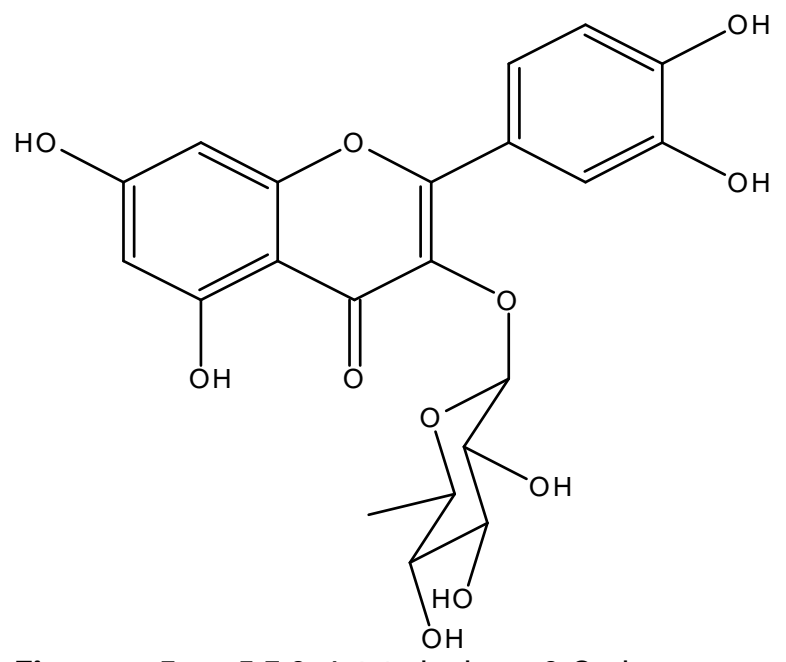

Figure 5: 5,7,3',4'-tetrahydroxy-3-O-glucopyranoside flavone (Quercetin- 3-O- $\beta$-rhamnopyranoside)

(Fraction 126-141)<smiles>O=c1c(O)c(-c2ccc(O)c(O)c2)oc2cc(O)cc(O)c12</smiles>

Figure 6: 3,5,7,3'4'-pentahydroxyflavone (Quercetine)

(Fraction 87-112)

\section{Acknowledgements}

Authors are thankful to CIMAP for providing the facilities and CSIR-TWAS for the offer of one year Postdoctoral fellowship to Dr S.W. Hassan.

\section{REFERENCES}

Arnold, H.J., Gulumian, M. (1984). Pharmacopoeia of traditional medicine in Venda. Journal of Ethnopharmacology, 12: 35-74

Atawodi, S.E. (2005). Antioxidant potential of African medicinal plants. African Journal of Biotechnology, 4(2): 128-133.

Bonjean, K., De Pauno-Gillet, M.C., De france, M.P. (1988). The DNA intercalating alkaloid crytolepine interacts with topoisomerase II and inhibits primary DNA synthesis in B16 melanocells. Biochemistry, 37: 5136-5146.

Burkill, H.M. (2000). The useful plants of West Africa, $2^{\text {nd }}$ Edition.Volume 5, Families S-Z, Addenda.
${ }^{1} \mathrm{H}$ NMR (MeOD, $\left.300 \mathrm{MHz}\right): \quad \delta 6.19(1 \mathrm{H}, \mathrm{d}, \mathrm{J}=2.2$ $\mathrm{Hz}, \mathrm{H}-6), 6.38(1 \mathrm{H}, \mathrm{d}, \mathrm{J}=2.2 \mathrm{~Hz}, \mathrm{H}-8), 6.88(1 \mathrm{H}, \mathrm{d}, \mathrm{J}$ $\left.=8.4 \mathrm{~Hz}, \mathrm{H}-5^{\prime}\right), 7.30\left(2 \mathrm{H}, \mathrm{m}, \mathrm{H}-2^{\prime} \& \mathrm{H}-6^{\prime}\right), 5.34(1 \mathrm{H}, \mathrm{d}$, $\left.\mathrm{J}=1.5 \mathrm{~Hz}, \mathrm{H}-1^{\prime \prime}\right), 3.90$ (1H, dd, J = 1.5, 3.3 Hz, H-2"), $3.72(1 \mathrm{H}, \mathrm{m}, \mathrm{H}-3$ "), 3.45 (1H, m, H-4"), $4.18(1 \mathrm{H}, \mathrm{m}$, $\mathrm{H}-5$ "), $0.93(3 \mathrm{H}, \mathrm{d}, \mathrm{J}=6.0 \mathrm{~Hz}, \mathrm{H}-6$ ")

${ }^{13} \mathrm{C}$ NMR (MeOD, $300 \mathrm{MHz}$ ): $\delta 158.26$ (C-2), 132.25 (C-3), 177.36 (C-4), 162.48 (C-5), 99.29 (C-6), 165.60 (C-7), 94.36 (C-8), 159.25 (C-9), 103.56 (C-10), 123.35 (C-1'), 116.72 (C-2'), 147.81 (C-3'), 147.18 (C$\left.4^{\prime}\right), \quad 116.72$ (C-5'), 122.93 (C-6'), 103.56(C-2"), $71.91(\mathrm{C}-3 ") 73.27$ (C-4") 79.45 (C-5") 72.03 (C-6"), 17.64 (C-7")

${ }^{1} \mathrm{H}$ NMR (Py, $\left.300 \mathrm{MHz}\right): \delta 6.74(1 \mathrm{H}, \mathrm{d}, \mathrm{J}=2.2 \mathrm{~Hz}, \mathrm{H}-$ 6), $6.78(1 \mathrm{H}, \mathrm{d}, \mathrm{J}=2.2 \mathrm{~Hz}, \mathrm{H}-8), 8.63\left(1 \mathrm{H}, \mathrm{s}, \mathrm{H}-2^{\prime}\right)$, $8.10\left(1 \mathrm{H}, \mathrm{d}, \mathrm{J}=8.4 \mathrm{~Hz}, \mathrm{H}-6^{\prime}\right), 7.40(1 \mathrm{H}, \mathrm{d}, \mathrm{J}=8.4 \mathrm{~Hz}$, $\left.\mathrm{H}-5^{\prime}\right)$

${ }^{13} \mathrm{C}$ NMR (Py, $\left.300 \mathrm{MHz}\right): \delta 157.26$ (C-2), 137.96 (C3), 177.36 (C-4), 162.48 (C-5), 99.29 (C-6), 165.60 (C-7), 94.36 (C-8), 157.50 (C-9), 104.50 (C-10), 123.35 (C-1'), 116.72 (C-2'), 147.81 (C-3'), 147.18 (C4'), 116.72 (C-5'), 121.12 (C-6')

Royal Botanic Gardens, Kew, Richmond, UK, PP 686

Etkin, N.L. (1997). Antimalarial plants used by Hausa in northern Nigeria. Tropical Doctor, 27: 12-16.

Gasquet, M., Delmas, F., Timon-David P, Keita,A., Guindo, M., Koita, N.,Diallo D., Doumbo O (1993). Evaluation in vitro and in vivo of a traditional antimalarial drug: malarial 5 . Fitoterapia, 64: 423-426.

Hassan, S.W., Lawal, M., Muhammad, B.Y., Umar, R.A., Bilbis, L.S., Farouk, U.Z., Ebo, A.A. (2007). Antifungal activity and phytochemical analysis of column chromatographic fractions of Ficus sycomorus stem bark extracts. Journal of Plant Science, 292: 209-215.

Hassan, S.W.,Verma, S., Srivastava , S.K., Luqman, S., Gupta, U., Masood, N. (2013). Activity guided isolation and characterization of antioxidant and antibacterial agents from some local Nigerian 
plants. African Journal of Biotechnology, 12(44): 6315-6325

Kim, Y.C., Kim,,H.S., Wataya, Y. Sohn, D.H., Kang, T.H., Kim, M.S., Kim, Y.M., Lee G.M., Chang, J.D., Park,H. (2004). Antimalarial activity of lavandulyl flavanones isolated from the roots of Sophora flavescens. Biological and Pharmaceutical Bullettin. 27(5): 748-750

Ladeji, O., Udoli, F.V., Okoye, Z.S. (2005). Activity of aqueous extract of the back of Vitex doniana on uterine muscle response to drugs. Phytotherapy Research, 19(9): 804-806

Mandu, P., Tengnas, B.O. (2005). Useful trees and shrubs for Kenya, World Agro forestry Centre.

Monbrison, F., Maitrejean,M., Latour C, Bugnazet, F., Peyron, F., Berron, D., Picot, S.(2006). In vitro antimalarial activity of flavonoid derivatives dehydrosilybin and 8-(1,1)-DMA Kaempferide. Acta Tropica, 97: 102-107

National Guidelines for Diagnosis and Treatment of Malaria (2011). Federal Ministry of Health, National Malaria and Vector Control Division, Abuja, Nigeria; from: http://www.nmcpnigeria.org/f/case-management/ National\%20Guidelines\%20on\%20Diagnosis\%20 $\% 20 \&$ Treatment $\% 20$ of\%20Malaria\%20in\%20Nig eria\%20June\%202011.pdf..

Okpanachi, A.O., Adelaiye, A.B., Dikko, A.A.U., Kabiru, M., Mohammed, A., Tanko, Y. (2010). Evaluation of the effect of aqueous methanolic stem bark of Acacia polyacanthia on blood glucose levels of aloxan induced diabetic wister rats. International Journal of animal and Veterinary Advances, 2(3): 5962.
Olanrewaju, W.I., Johnson, A.W.B.R. (2001). Chloroquine-resistant Plasmodium falciparum malaria in Ilorin, Nigeria. Prevalence and risk factors for treatment failure. African Journal of Medical Science, 30: 165-169.

Oliveira, F.Q., Andrade-Neto V., Krettli, A.U., Brando, M.G. (2004). New evidences of antimalarial activity of Bidens pilosa root extract correlated with polyacetylene and flavonoids. Journal of Ethnopharmacology, 93(1): 39-42

Peters, W., Davies, E.F., Robinson, B.L. (1975). The chemotherapy of rodent malaria, XXIII. Casual prophylaxis II. Practical experience with Plasmodium yoelii nigeriensis in drug screening. Annals of Tropical Medical Parasitology, 69: 311328.

Samy, C.K.T., Dankwa, K., Stephen, Y.G., Archibald, S. (2011). Antimalarial activity of Cryptolepis anguinolenta based herbal capsules in Plasmodium berghei infected mice. International Research Journal of Pharmacy, 2(5): 127-131.

Vial, H. (1996). Recent development and rationale towards new strategies for malarial chemotherapy. Parasite, 3: 3-23.

Wernsdorfer, W.H., Trigg, P.I. (1988). Recent progress of malaria research: chemotherapy. In: Wensdorfer WH, McGregor I(eds). Malaria principle and practice of malariology, vol. 2. Churchill Livingstone, London, pp:1569-1674.

World Health Organization, World Malaria Report (2012) http://www.who.int/malaria

Zimmerman, M., (1983). Ethical guidelines for investigation of experimental pain in conscious animal. Pain, 16: 109110. 